\title{
Molecular Mapping of Hypersensitive Resistance from Tomato 'Hawaii 7981' to Xanthomonas perforans Race T3
}

\author{
Hui Wang, Samuel F. Hutton, Matthew D. Robbins, Sung-Chur Sim, Jay W. Scott, \\ Wencai Yang, Jeffrey B. Jones, and David M. Francis
}

First and sixth authors: Department of Vegetable Science, College of Agronomy and Biotechnology, China Agricultural University, Beijing 100193; first, third, fourth, and eighth authors: Department of Horticulture and Crop Science, Ohio Agricultural Research and Development Center, The Ohio State University, 1680 Madison Ave., Wooster 44691; second and fifth authors: Department of Horticulture, Gulf Coast Research and Education Center, University of Florida, 14625 CR 672, Wimauma 33598; and seventh author: Department of Plant Pathology, University of Florida, Fifield Hall, P.O. Box 110680, Gainesville 32611.

Accepted for publication 22 April 2011.

\section{ABSTRACT}

Wang, H., Hutton, S. F., Robbins, M. D., Sim, S.-C., Scott, J. W., Yang, W.-C., Jones, J. B., and Francis, D. M. 2011. Molecular mapping of hypersensitive resistance from tomato 'Hawaii 7981 ' to Xanthomonas perforans race T3. Phytopathology 101:1217-1223.

Bacterial spot of tomato (Solanum lycopersicum) is caused by four species of Xanthomonas. The disease causes significant yield losses and a reduction in fruit quality. Physiological races have been described with tomato race 3 (T3) corresponding to strains of Xanthomonas perforans. The breeding line Hawaii 7981 (hereafter H7981) shows a hypersensitive reaction (HR) to race $\mathrm{T} 3$ strains conditioned by the interaction of the host resistance locus $X v 3$ and the bacterial effector $a v r X v 3$. The $X v 3$ gene is required for H7981-derived resistance to be effective under field conditions, though its expression is subject to genetic background. The segregation of $\mathrm{HR}$ in $\mathrm{F}_{2}$ populations derived from $\mathrm{H} 7981$ crossed to processing tomato parents $\mathrm{OH} 88119$ and $\mathrm{OH} 7870$ was studied in 331 progeny, with the two independent crosses providing validation. We screened 453 simple-sequence repeat, insertion/deletion, and singlenucleotide polymorphism markers and identified 44 polymorphic markers each for the $\mathrm{OH} 88119$ and $\mathrm{OH} 7870$ populations covering 84.6 and $73.3 \%$ of the genome, respectively, within 20 centimorgans (cM). Marker-trait analysis using all polymorphic markers demonstrated that $X v 3$-mediated resistance maps to chromosome 11 in the two independent crosses. Allelism tests were conducted in crosses between lines carrying $X v 3$ derived from H7981, $R x-4$ derived from plant introduction (PI) 128216, and resistance derived from PI 126932. These allelism tests suggested that the loci conditioning HR to race T3 strains are linked within $0.1 \mathrm{cM}$, are allelic, or are the same gene.

Additional keywords: single-nucleotide polymorphism.
Bacterial spot is among the most important diseases of fieldgrown tomato (Solanum lycopersicum L.) produced in humid environments (10). The disease causes yield losses through reduced photosynthetic capacity and defoliation. Fruit quality is reduced indirectly due to sunscald or cracking and directly by bacterial lesions. Bacterial spot of tomato is caused by four species of Xanthomonas, including Xanthomonas euvesicatoria (ex Doidge 1921) (5) sp. nov., sp. rev.; X. vesicatoria (38); X. perforans (11) sp. nov.; and $X$. gardneri (33) sp. nov. (11).

In addition, five races (T1 to T5) are recognized on the basis of hypersensitive reaction (HR) expression using a differential series of host genotypes (9-11). Races T1 to T3 were recognized on tomato based on their reaction on Hawaii 7998 (H7998), H7981, and a susceptible control $(13,14,19,31)$. T1 strains correspond to $X$. euvesicatoria and carry the effector $a v r R x v$ which induces HR on the genotype H7998 (43). T2 strains correspond to $X$. vesicatoria and do not induce an $\mathrm{HR}$ on either of the indicator cultivars. Race T3, T4, and T5 strains tend to be $X$. perforans. HR-inducing resistance to T3 strains has been identified in H7981 and S. pimpinellifolium accessions plant introduction (PI) 126932

Corresponding author: David M. Francis, E-mail address: francis.77@ osu.edu

* The $\boldsymbol{e}$-Xtra logo stands for "electronic extra" and indicates that the online version contains one supplemental table.

doi:10.1094/PHYTO-12-10-0345

This article is in the public domain and not copyrightable. It may be freely reprinted with customary crediting of the source. The American Phytopathological Society, 2011. and PI $128216(2,20,26)$. The HR in H7981, PI 126932, and PI 128216 is mediated by the same pathogen effector, $a v r X v 3$ (14). Resistance to $a v r X v 3$ was overcome in 1998 by the emergence of race T4 strains (2,35). S. pennellii accession LA716 is reported to have HR-inducing resistance to T4 strains (2). In addition, resistance to races $\mathrm{T} 1$ to $\mathrm{T} 4$ of bacterial spot has been described in the S. lycopersicum var. cerasiforme accession, PI 114490. The accession PI 114490 does not display an HR; rather, resistance is based on a quantitative reduction of disease in field evaluations $(24,28)$.

Progress has been made to precisely characterize the genetics of resistance from diverse sources (Table 1). Resistance from H7998 to race T1 was demonstrated both in the field (25) and as HR in the greenhouse (12). In a wide cross between H7998 and LA716, HR-inducing resistance loci $R x-1$ and $R x-2$ mapped to opposite ends of chromosome 1, and $R x-3$ mapped to chromosome 5. All three loci appear to interact with avrRxv $(40,41,47)$. Of the three HR-inducing loci from H7998, only $R x$-3 was effective in the field based on an intraspecific cross (46). Resistance derived from PI 114490 to race T2 appears complex, with multiple quantitative trait loci involved (24,45). HR-based resistance to race T3 strains derived from PI 128216 mapped as a single locus, $R x-4$, to chromosome 11 (22). This locus was effective in the field but the degree of resistance depended on the genetic background, suggesting that other loci may modify the expression of resistance (22). Based on classical analysis, field resistance to $\mathrm{T} 3$ from $\mathrm{H} 7981$ is quantitatively inherited and is based on $X v 3$, which is partially dominant, and modifier loci (27). $\mathrm{H} 7981$ has been used as a donor to introduce resistance to T3 
strains into elite genetic backgrounds (26) and, thus, is a desirable resistance to characterize. The published map position for resistance to T4 strains from LA716 (2) has not been verified and studies are ongoing to clarify the genetics of this source of resistance. Resistance to T4 strains from PI 114490 appears to be complex, with multiple quantitative trait loci involved $(7,8)$.

The emergence of new races even before the widespread commercial deployment of resistance suggests a need to combine (pyramid) multiple sources of resistance. This task can be facilitated by DNA-based marker-assisted selection (MAS) once the linkage between resistance and sequence variation has been established. Despite the availability of molecular markers that cover the entire tomato genome in an interspecific cross $(6,34)$, genetic analysis of intraspecific crosses has been limited because of the lack of polymorphic markers. This issue is particularly problematic for studies of bacterial spot resistance due to the predominance of $S$. lycopersicum sources of resistance. Recent attempts to use emerging genomic resources have resulted in the identification of single-nucleotide polymorphisms (SNPs) between cultivated varieties $(16,30,36,42,44)$. These SNP resources are being leveraged to facilitate the genetic analysis of bacterial spot resistance, and have been used to select resistant genotypes (22).

The main objective of this study was to use molecular markers to identify the genomic region of the locus $X v 3$ derived from the tomato breeding line H7981. Our goal was to develop DNA-based markers to facilitate selection of resistant cultivars. In addition, mapping $X v 3$ also allowed us to assess the relationship between resistance in H7981, PI 126932, and PI 128216 in order to determine whether these sources might be complementary.

\section{MATERIALS AND METHODS}

Plant materials and experimental design. We developed six populations to study the inheritance of $X v 3$-mediated HR resistance to bacterial spot race T3. Two populations were developed to confirm the inheritance of $X v 3$ and test for marker-trait associations. Resistant and susceptible parents were crossed and the $F_{1}$ from these crosses were self-pollinated to produce $F_{2}$ seed. The population derived from crossing H7981 × OH88119 consisted of 170 individuals and was also the basis for linkage map construction. The $\mathrm{H} 7981 \times \mathrm{OH} 7870$ population consisted of 161 progeny. OH88119 is an elite processing tomato parent chosen because of its early and concentrated fruit set as well as susceptibility to bacterial disease (3). The OH7870 parent is considered susceptible to T3 strains based on a failure to elicit an HR reaction but contains a nonblighting field resistance to bacterial spot. The relationship between loci controlling HR from H7981, PI 128216, and PI 126932 was studied using a series of crosses to determine allelism, and are described in the results. Briefly, we crossed Florida (Fla.) 8517 (T3 HR from PI 128216) to Fla. 8000
(T3 HR from H7981), Fla. 8233 (T3 HR from PI 128216) to Fla. 8326 (T3 HR from PI 126932), and Fla. 8326 to Fla. 8517. The $F_{1}$ plants were subsequently self-pollinated to produce $\mathrm{F}_{2}$ seed. For a segregating control, Fla. 8517 was crossed to the susceptible breeding line Fla. 8021, and the $\mathrm{F}_{1}$ was subsequently self-pollinated to produce $F_{2}$ seed. In spring $2009, F_{1}$ and $F_{2}$ generations of crosses, selected parents of those crosses, and $\mathrm{H} 7981$ were grown in the greenhouse at temperatures of 25 to $35^{\circ} \mathrm{C}$ for 4 to 5 weeks before inoculation and evaluation of HR.

The growth and care of greenhouse plants followed established methods (46). Tomato seed for all studies were sown in 288-cell flats. At 4 to 6 weeks after germination, seedlings were transplanted into 10.2-cm plastic pots filled with MetroMix-510 growing medium (Premier Horticulture, Inc., Red Hill, PA). Inoculations were performed within 2 weeks posttransplanting.

Inoculum preparation and inoculation. The $X$. perforans race T3 strains used in the study were Xcv761 (23) and SM45-07 and were kindly provided by Sally Miller, Department of Plant Pathology, The Ohio State University, and XcT3 B (for allelism tests). Bacterial strains were grown on yeast, dextrose, and calcium carbonate (YDC) agar medium (18) at $28^{\circ} \mathrm{C}$ for 48 to $72 \mathrm{~h}$. Bacterial cells were removed from the agar plates with sterile, double-distilled water and the suspensions were standardized to absorbance at $600 \mathrm{~nm}=0.15$, a concentration corresponding to $\approx 3 \times 10^{8} \mathrm{CFU} / \mathrm{ml}$. For evaluations of $\mathrm{HR}$ in the greenhouse, inoculations were performed by subepidermal injection. One leaflet on each plant was inoculated with sterile $\mathrm{H}_{2} \mathrm{O}$ to provide a comparison. Two leaflets per strain on each plant were inoculated with bacteria. The bacterial suspension $(200 \mu \mathrm{l})$ was injected on the underside of each young, fully expanded leaflet using a 3-ml syringe without a needle until the area of infiltration reached a diameter of $1.5 \mathrm{~cm}$. Resistant and susceptible parents and $\mathrm{F}_{1}$ plants were all inoculated to provide controls. Plants were kept at 20 to $25^{\circ} \mathrm{C}$ in the greenhouse with ambient lighting supplemented by a 1:1 mix of high-pressure sodium and metal halide lamps such that light intensity was maintained at 1,250 to 800 micromole $/ \mathrm{m}^{2} / \mathrm{s}$ within 400 to $700 \mathrm{~nm}$ for $14 \mathrm{~h} /$ day.

Disease evaluation. Plants were scored for the HR response in the greenhouse by monitoring them for confluent necrosis at 24, 48 , and $72 \mathrm{~h}$ after inoculation. Each of the two inoculated leaves per plant was scored as either HR (resistant $=0$ ) or susceptible $(=1)$. The scores from both leaves were combined into a single score for each plant for qualitative data analysis. If one of the leaves showed no response and the other showed a clear response, the plant was scored according to the clear response. Scores were also combined into a quantitative response score based on assigning values of 0 (resistant) or 1 (susceptible) for each of the two inoculations and each of the three evaluation days. The quantitative disease rating was based on the sum of the average daily scores such that the 0 or 1 qualitative score was translated into a 0 to 3 quantitative score representing the combined ratings over

TABLE 1. Summary of Xanthomonas spp., bacterial effectors, and sources of resistance mediating the bacterial spot-tomato interaction

\begin{tabular}{|c|c|c|c|c|c|c|c|}
\hline Species & $\begin{array}{l}\text { Physiological } \\
\text { race }\end{array}$ & $\begin{array}{c}\text { Bacterial } \\
\text { effector }\end{array}$ & $\begin{array}{l}\text { Effector } \\
\text { reference }\end{array}$ & Source & Locus & Map position & $\begin{array}{l}\text { Resistance } \\
\text { reference }\end{array}$ \\
\hline \multirow[t]{3}{*}{ Xanthomonas euvesicatoria } & $\mathrm{T} 1$ & avrRxv & 43 & H7998 & $R x-1$ & 1 & 47 \\
\hline & $\mathrm{T} 1$ & avrRxv & 43 & H7998 & $R x-2$ & 1 & 47 \\
\hline & $\mathrm{T} 1$ & avrRxv & 43 & H7998 & $R x-3$ & 5 & 46,47 \\
\hline \multirow[t]{6}{*}{$X$. perforans } & $\mathrm{T} 3$ & avrXv3 & 20 & PI 128216 & $R x-4$ & 11 & 22 \\
\hline & $\mathrm{T} 3$ & avrXv3 & 20 & H7981 & $X v 3$ & 11 & This article \\
\hline & $\mathrm{T} 3$ & avrXv3 & 20 & PI 126932 & $X v 3$ & 11 & This article \\
\hline & $\mathrm{T} 4$ & $\operatorname{avrXv4}$ & 2 & LA716 & $X v 4$ & $\mathrm{NW}^{\mathrm{a}}$ & 2 \\
\hline & $\mathrm{T} 4$ & $\ldots$ & $\ldots$ & PI 114490 & $\mathrm{QTL}^{\mathrm{b}}$ & $\ldots$ & 8 \\
\hline & $\mathrm{T} 5$ & $\ldots$ & $\ldots$ & $\ldots$ & $\ldots$ & $\ldots$ & $\ldots$ \\
\hline$X$. vesicatoria & $\mathrm{T} 2$, other & $\ldots$ & $\ldots$ & PI 114490 & $\mathrm{QTL}^{\mathrm{b}}$ & $\ldots$ & 8,24 \\
\hline$X$. gardneri & $\mathrm{T} 2$, other & $\ldots$ & $\ldots$ & $\ldots$ & $\ldots$ & $\ldots$ & $\ldots$ \\
\hline
\end{tabular}

a The published map position, on chromosome 3 , has not withstood further testing.

b Multiple quantitative trait loci. 
3 days. Single plants with ambiguous responses were excluded from the statistical analysis.

Evaluation was based on $\mathrm{F}_{2}$ plants which, by nature, are unique individuals and, therefore, difficult to replicate in the traditional sense. Our experimental design was based on replicate inoculations for each $\mathrm{F}_{2}$ plant with plants inoculated four times, twice each with two different strains. Each population was inoculated separately in time, and analysis (below) was conducted separately for each population. To assess marker-trait associations (detailed below), the population was grouped by genotypes (P1, Heterozygous, or P2), and therefore, replication was based on the number of individual $\mathrm{F}_{2}$ plants analyzed ( $n=170$ for the OH88119 population and $n=161$ for the $\mathrm{OH} 7870$ population).

DNA extraction. DNA extraction was performed using a modified hexadecyltrimethylammonium bromide (CTAB) method (15) scaled for 96-well format. Fresh young leaf tissue $(\approx 0.2 \mathrm{~g})$ from each plant was collected into $1.2 \mathrm{ml}$ tubes in a 96-well array (Corning Incorporated, Corning, NY). Tissue was macerated in $350 \mu \mathrm{l}$ of DNA extraction-lysis buffer mixture (nucleic lysis buffer [0.2 M Tris, 0.05 M EDTA, $2 \mathrm{M} \mathrm{NaCl}$, and 2\% CTAB, $\mathrm{pH}$ 7.5], $30 \mathrm{mM}$ sodium bisulfite, DNA extraction buffer [0.1 M Tris, $5 \mathrm{mM}$ EDTA, and $0.35 \mathrm{M}$ sorbitol, pH 7.5], and 5\% sarkosyl) containing two $4 \mathrm{~mm}$ metal balls by shaking in a GenoGrinder (BT\&C/OPS Diagnostics, Bridgewater, NJ) at 500 strokes/min for $3 \mathrm{~min}$. The homogenate was incubated at $65^{\circ} \mathrm{C}$ for $20 \mathrm{~min}$. Following incubation, $350 \mu \mathrm{l}$ of chloroform/isoamyl alcohol (24:1) was added and the homogenate was centrifuged for $10 \mathrm{~min}$ at $5,000 \times g$. The aqueous phase was transferred to a new plate and $125 \mu \mathrm{l}$ of isopropanol was added to precipitate the DNA. The DNA was resuspended in $100 \mu \mathrm{l}$ of Tris EDTA buffer containing $1 / 10$ the normal amount of EDTA $(10 \mathrm{mM}$ Tris- $\mathrm{HCl}, \mathrm{pH} 7.5$ to 8.0, and $0.1 \mathrm{mM}$ EDTA). DNA concentration for polymerase chain reaction (PCR) analysis was calibrated on the basis of ethidium bromide fluorescence using a size standard with known nanogram quantities of DNA for each band as a quantitative standard.

Molecular markers and genotyping. Initial genotyping focused on a survey across all chromosomes. We used the Tomato Mapping Resource database (http://www.tomatomap.net/) to identify markers that were polymorphic between OH88119 and H7981. Potential polymorphic markers for OH7870 were inferred based on patterns for Campbell 28 (C28), a major contributor to the pedigree, and $\mathrm{OH} 8245$, a progeny line derived from $\mathrm{OH} 7870$. Our goal was to identify two markers per chromosome arm in order to survey the genome. This approach identified multiple marker types, including simple-sequence repeat (SSR), insertion/deletion (Indel), and single-nucleotide polymorphism (SNP) markers. All markers used in this study were reported elsewhere $(36,44)$. A summary of markers is provided as a supplementary table (Supplemental Table 1). Primers used to detect key intervals are described in the results. We divided genotyping into fragment analysis and SNP assays.

Fragment analysis of SSR and Indel markers was conducted with a LI-COR IR2 4200 system (LI-COR Biosciences, Lincoln, $\mathrm{NE})$. PCR reactions were conducted in a $10 \mu \mathrm{l}$ volume. Each reaction consisted of $1 \mu \mathrm{l}$ of $10 \times$ buffer A mixture (100 mM Tris$\mathrm{HCl}$ [pH 8.3], $500 \mathrm{mM} \mathrm{KCl}, 15 \mathrm{mM} \mathrm{MgCl}$, and $0.01 \%$ [wt/vol] gelatin), $1.25 \mu \mathrm{M}$ each dNTP, $10 \mu \mathrm{M}$ IRD 700 dye-labeled M-13 forward primer (LI-COR Biosciences), $10 \mu \mathrm{M}$ each M-13 tailed forward primer, $10 \mu \mathrm{M}$ each reverse primer, genomic DNA template at $1 \mathrm{ng} / \mu \mathrm{l}$, and 1 unit of Taq DNA polymerase. Reactions were heated at $94^{\circ} \mathrm{C}$ for $2 \mathrm{~min}$ followed by 36 cycles of $45 \mathrm{~s}$ at $94^{\circ} \mathrm{C}, 45 \mathrm{~s}$ at an annealing temperature suitable to the specific marker, and a $45 \mathrm{~s}$ extension at $72^{\circ} \mathrm{C}$. Final reactions were extended at $72^{\circ} \mathrm{C}$ for $5 \mathrm{~min}$. Amplification was performed in a programmable thermal controller (PTC-100; MJ Research, Inc., Watertown, MA). Following the amplification reactions, $9 \mu \mathrm{l}$ of the amplification reaction products were mixed with $4.5 \mu \mathrm{l}$ of formamide loading buffer (95\% formamide, $20 \mathrm{mM}$ EDTA, $\mathrm{pH}$ 8.0, and bromophenol blue), denatured at $95^{\circ} \mathrm{C}$ for $3 \mathrm{~min}$, and then chilled immediately to $4^{\circ} \mathrm{C}$. A maximum of six samples was combined for multiplexing and $0.8 \mu \mathrm{l}$ was loaded into a $6.5 \%$ denaturing gel $(25 \mathrm{ml}$ of $6.5 \%$ gel matrix, $150 \mu \mathrm{l}$ of fresh $10 \%$ APS, and $15 \mu \mathrm{l}$ of TEMED) using an eight-channel Hamilton syringe (Hamilton Company, Reno, NV). IRD-labeled molecular markers (LI-COR) were loaded in two-end lanes as a standard. Electrophoresis was performed at constant power (40 W). Data were collected using the Saga Generation 2 software package (LICOR), including automated band calling and size determination. Sizes were verified in reference to the Tomato Mapping Resource database.

SNP markers were detected using either cleaved amplified polymorphisms (CAPs) or allele-specific primer extension (ASPE) assays (17). CAPs were detected using restriction digestion of amplified products according to the methods described previously (44). Restriction enzymes were purchased from New England BioLabs Incorporated (Ipswich, MA) and Fermentas Inc. (Glen Burnie, MD). PCR reactions for ASPE assays were conducted in $15 \mu \mathrm{l}$ of reaction volume. Each reaction consisted of $1.5 \mu \mathrm{l}$ of $10 \times$ buffer A mixture (100 mM Tris- $\mathrm{HCl}[\mathrm{pH} 8.3$, $500 \mathrm{mM} \mathrm{KCl}, 15 \mathrm{mM} \mathrm{MgCl}_{2}$, and $0.01 \%$ [wt/vol] gelatin), $1.25 \mu \mathrm{M}$ each dNTP, $10 \mu \mathrm{M}$ each forward primer, $10 \mu \mathrm{M}$ each reverse primer, genomic DNA template at $1 \mathrm{ng} / \mu \mathrm{l}$, and 1 unit of Taq DNA polymerase. A maximum of 12 PCR reactions was combined and ethanol precipitated. Products were suspended in $8 \mu \mathrm{l}$ of distilled sterile $\mathrm{H}_{2} \mathrm{O}$. DNA suspension $(4 \mu \mathrm{l})$ was combined with $1 \mu \mathrm{l}$ of $10 \times$ ASPE reaction buffer $(200 \mathrm{mM}$ Tris- $\mathrm{HCl}$ [pH 8.4], $500 \mathrm{mM} \mathrm{KCl}), 0.25 \mu \mathrm{l}$ of $50 \mathrm{mM} \mathrm{MgCl}_{2}, 0.5 \mu \mathrm{l}$ of $500 \mathrm{nM}$ each TAG-ASPE primer, $0.075 \mu \mathrm{l}$ of Tsp DNA polymerase at $5 \mathrm{U} / \mu \mathrm{l}, 0.5 \mu \mathrm{l}$ of $100 \mathrm{nM}$ dNTP mixture, and $0.125 \mu \mathrm{l}$ of $400 \mu \mathrm{M}$ biotin-dCTP (100 mM Tris- $\mathrm{HCl}[\mathrm{pH} 7.5]$ and $0.1 \mathrm{mM}$ EDTA). The ASPE reaction was run at $96^{\circ} \mathrm{C}$ for $2 \mathrm{~min}, 94^{\circ} \mathrm{C}$ for $30 \mathrm{~s}, 55^{\circ} \mathrm{C}$ for $1 \mathrm{~min}$, and $74^{\circ} \mathrm{C}$ for $2 \mathrm{~min}$ for 30 cycles. Samples were then chilled to $4^{\circ} \mathrm{C}$. Following the ASPE reaction, primertagged fluorescent FlexMAP microspheres were added to the samples. The samples were vortexed and heated to $96^{\circ} \mathrm{C}$ for $90 \mathrm{~s}$. These were subsequently hybridized for $1 \mathrm{~h}$ at $37^{\circ} \mathrm{C}$. The reaction was washed by centrifugation at 2,250 $\times g$ and resuspended in a solution of $0.4 \mathrm{M} \mathrm{NaCl}, 0.2 \mathrm{M}$ Tris ( $\mathrm{pH} 8.0$ ), and $0.16 \%$ Triton X100. Washing was repeated twice and the reaction was suspended in $40 \mu \mathrm{l}$ of wash buffer containing streptavidin-R-phycoerythrin at $4 \mu \mathrm{g} / \mathrm{ml}$. Samples were revortexed and incubated for $30 \mathrm{~min}$ at $37^{\circ} \mathrm{C}$. Bead fluorescence was subsequently analyzed using the Luminex 200 system (Luminex Corporation, Austin, TX).

Statistical analysis. In the $\mathrm{F}_{2}$ populations, molecular marker genotypes were scored as homozygous for H7981 (resistant parent), homozygous for OH88119 or OH7870 (susceptible parent), and heterozygous. The populations were analyzed separately. Marker-trait associations were tested for significance using the nonparametric Kruskal-Wallace test as implemented in the SAS statistical software procedure NPAR1WAY with the Wilcoxon option specified (SAS version 9.2; SAS Institute, Cary, NC).

Genotyping and data analysis was performed with two iterations. Initially, the $\mathrm{OH} 7981 \times \mathrm{OH} 88119$ and $\mathrm{H} 7981 \times \mathrm{OH}_{7870} \mathrm{~F}_{2}$ populations were scored with 62 markers spanning the genome: 44 polymorphic markers for each population with 26 markers in common. Positive to marginally nonsignificant associations were then pursued by adding 13 markers from chromosome 11, 2 from chromosome 4, and 1 from chromosome 9. Additional markers were added based on further screening, with the lack of polymorphic markers precluding more dense coverage. A Genetic linkage map for chromosome 11 was created from these data using JoinMap 3.0 (37). For mapping purposes, the phenotypic data for the HR response was treated as both a dominant marker and a quantitative rating across all three time periods (as described above). Interval mapping of the quantitative rating was 
conducted for chromosome 11 because this was the only chromosomal region where reproducible marker-trait associations were detected. Composite interval mapping (CIM) was performed using the multi-quantitative trait loci (QTL) method with the program MapQTL 4.0 using automatic cofactor selection analysis (37). A permutation test (4) was performed with 1,000 runs to determine the genome-wide significance level for declaring a significant QTL. The log of the likelihood ratio (LOD) threshold of 3.1 was determined to correspond to $P=0.01$ and was taken as the estimated critical value at which to declare the presence of a QTL. The proportion of the phenotypic variance explained by the QTL effects was estimated by CIM at the QTL peak. A genetic map with an LOD plot was subsequently created using the MapChart 2.1 program (39) based on the outputs from JoinMap 3.0 and MapQTL 4.0.

Allelism was evaluated for linked genes in repulsion phase using the maximum likelihood equation for determining recombination values for the expected 15:1 segregation (resistant) $\times$ $(-2 \mathrm{P}) /\left(4-\mathrm{P}^{2}\right)+($ susceptible $) \times(2 / \mathrm{P})$ as described by Allard $(1)$. The standard error associated with the estimate was calculated as the square root of 1 /information $\times n$, where information = $4 /\left(4-\mathrm{P}^{2}\right)$ for the expected segregation (1).

\section{RESULTS}

Phenotypic evaluation. By $48 \mathrm{~h}$, all resistant parent plants and all $\mathrm{F}_{1} \mathrm{~s}$ exhibited confluent necrosis. At this time, evaluation of the populations in the greenhouse demonstrated a clear separation between the HR response and susceptibility. At the 72-h scoring, water-soaked lesions were often evident in susceptible progeny, whereas resistant progeny displayed a dry necrotic lesion. At the 24-h scoring, $94 \%$ of plants gave consistent results across the four inoculations. At the 72 -h scoring, $99 \%$ of the plants gave consis-

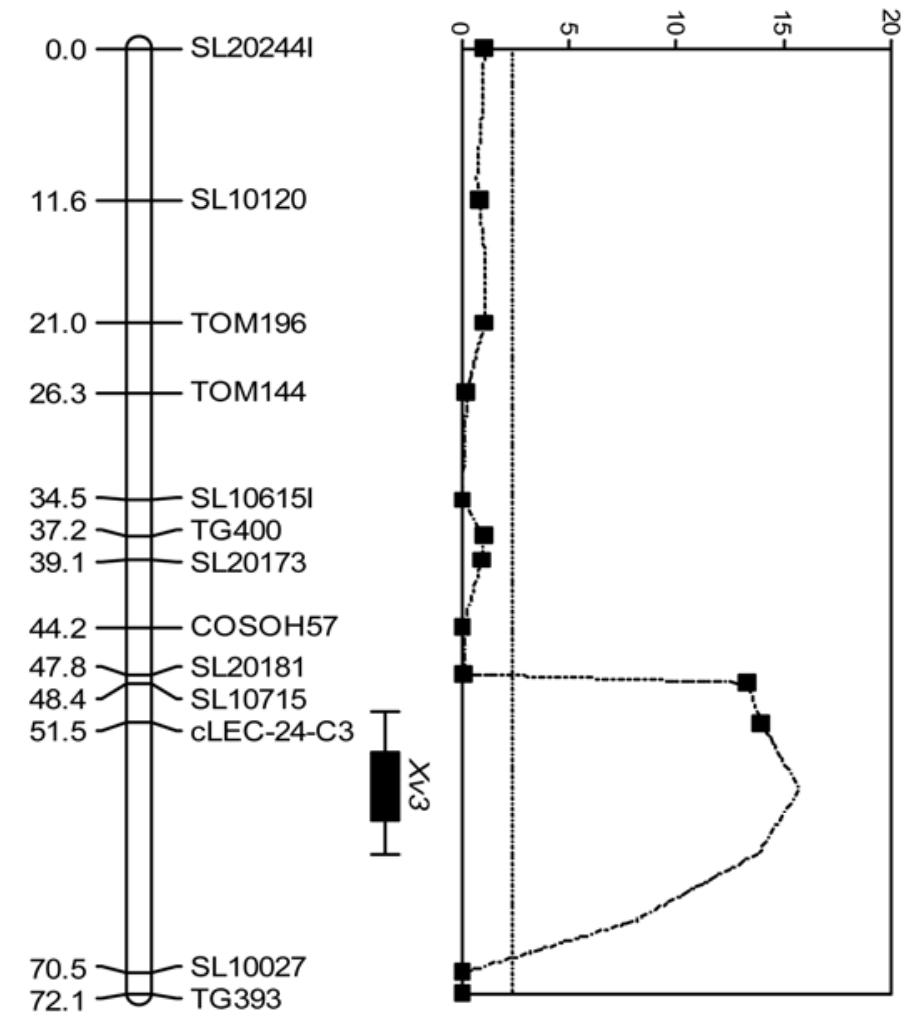

Fig. 1. Genetic linkage map showing the location of $X v 3$ on chromosome 11 of tomato. Genetic map shows map distances in centimorgans and are indicates marker names. Log of the likelihood ratio (LOD) trace is based on composite interval mapping. The central box represents the best map position for $X v 3$, with the 2-LOD confidence interval indicated by the error bars and the 1-LOD interval indicated by the box. tent results across all four inoculations. At $24 \mathrm{~h}, 3: 1$ segregation was rejected for both the OH88119 population $(P<0.01)$ and the OH7870 population $(P<0.01)$ due to an excess of progeny lacking evident necrosis and scored as susceptible. The segregation ratio for the OH88119 population was consistent with a $3: 1$ ratio at $48 \mathrm{~h}(P=0.34)$ and $72 \mathrm{~h}(P=0.25)$ of scoring. Segregation in the population based on $\mathrm{OH} 7870$ was also consistent with a $3: 1$ ratio at $48 \mathrm{~h}(P=0.64)$ and $72 \mathrm{~h}(P=0.68)$ of scoring.

Genetic mapping. In total, 453 markers were tested and 62 markers were identified as polymorphic, with 44 unique to each population and 26 in common to both populations. These markers covered all 12 tomato chromosomes and were used to genotype progeny from the OH88119 and OH7870 populations. Markertrait associations were tested using nonparametric analysis and we identified three candidate loci on chromosome 4, 9, and 11 in the H7981 $\times$ OH88119 population using $P<0.05$ as a cut-off. Only the chromosome 11 association was significant at $P<0.001$ and also was detected in the $\mathrm{OH} 7870$ population. We used the H7981 $\times$ OH88119 population to focus subsequent analysis on the three candidate chromosomes by adding markers to those regions. The analysis indicated that the major gene, $X v 3$ from H7981, mapped to chromosome 11 and failed to confirm further marker-trait associations on chromosomes 4 and 9. A location for $X v 3$ on chromosome 11 was validated by analysis in two independent crosses involving 331 progeny.

A genetic linkage map for the region of chromosome 11 was created based on 13 markers and the $F_{2}$ population derived from the cross between H7981 and OH88119 (Fig. 1). Markers did not deviate from the expected 1:2:1 ratio based on a $\chi^{2}$ test (data not shown). The marker order for the framework map was consistent with previous maps of the region (20). Qualitative scoring of the HR response was treated as a dominant marker and subsequently added to the map in order to determine the most likely position of $X v 3$. Qualitative analysis placed $X v 3$ near the middle of the short arm of chromosome 11 between markers cLEC-24-C3 (F: CAGACTGGAGAGTCAAAGGT; R: CCTTGCTGATAATCTG CAAGTTGTTAA) and SL10027 (F: GATCCAGTTTCCCTC TTACCG; R:CCATTAGAGCCAAGACGCTC) (Fig. 1). Phenotypic evaluation on a quantitative scale supported the map position between cLEC-24-C3 and SL10027 (Fig. 1). This analysis suggested that the region surrounded by cLEC-24-C3 and SL10027 explained 30 to $40 \%$ of the observed variation in HR response over the evaluation period. This analysis also allowed us to place a confidence interval (CI) surrounding the map position. The 1 LOD CI spanned 4 centimorgans (cM), beginning at marker cLEC-24-C3 and oriented toward the distal part of the chromosome. The CI suggests a location closer to the cLEC-24C3 marker than the SL10027 marker (Fig. 1).

The map position of $X v 3$ suggested a location in the same large interval as $R x-4$ derived from PI 128216 (22). We compiled a summary of all chromosome 11 markers in resistant germplasm by genotyping PI 128216 and a resistant IBC parent 06.8145 derived from this source (22) with the same set of markers used to characterize resistance from H7981 (Table 2). Although the two resistant lines, PI 128216 and H7981, share flanking marker genotypes at cLEC-24-C3 and SL10027, marker C2_At1g07960 within this interval distinguished the resistant parents (Table 2). Thus, the large interval is not inherited directly by descent.

Allelism tests. Tests of allelism failed to identify $F_{2}$ progeny derived from $R x-4 \times X v 3$ crosses that were susceptible (Table 3 ). Independent assortment of the two loci can be rejected $(P<$ $0.0001)$. In addition, crosses with HR resistance derived from PI 128216 and PI 126932 also yielded no susceptible $F_{2}$ progeny. For a population size of $341 \mathrm{~F}_{2}$, we expect $\approx 20$ susceptible individuals if the loci assort independently. Failure to identify a single susceptible individual suggests that the loci are within $0.1 \pm$ 
$0.3 \mathrm{cM}$. Though marker data does not support the idea that the chromosome segments carrying resistance are identical, we may conclude that HR-inducing loci $R x-4$ and $X v 3$ are closely linked and possibly allelic. Similarly, HR from PI 126932 appears to be closely linked and possibly allelic.

\section{DISCUSSION}

We located the $X v 3$ locus derived from H7981 to chromosome 11 in the same region as $R x-4$ derived from PI 128216. The population sizes provided sufficient power to support a 3:1 segregation and exclude other ratios, providing evidence for a single gene. Scott et al. (29) reported $X v 3$ to be an incompletely dominant gene, where the homozygous HR plants had confluent necrosis at $24 \mathrm{~h}$ and the heterozygotes at $48 \mathrm{~h}$. This result appears to be consistent with our findings, where the 3:1 ratio was supported at 48 but not $24 \mathrm{~h}$. In all, 31 individual plants were scored as susceptible at $24 \mathrm{~h}$ but resistant at $48 \mathrm{~h}$. All but one were heterozygous for flanking markers, suggesting a delay in response when resistance is heterozygous. The locus on chromosome 11 alone was sufficient to confer HR. Crosses between breeding lines carrying $R x-4$ and $X v 3$ resistance suggest that the two sources of resistance are closely linked, allelic, or even the same locus. Similarly, crosses between lines carrying HR from PI 128216 and PI 126932 demonstrate that these resistances are also closely linked, allelic, or the same locus. Although many of the polymorphisms flanking resistance in H7981 and PI 128216 are identical, C2_At1g07960 distinguishes the two parents. Thus, we cannot confirm that segments carrying resistance are identical by descent. Larger populations and the identification of more polymorphisms in the area will be required to determine whether $R x-4$ and $X v 3$ are closely linked genes that interact with the same bacterial effector or are alleles of the same locus.

Formal proof of allelism and/or gene identity is not necessary to guide practical decisions regarding the use of resistance sources. HR resistance in H7981, PI 128216, PI 126932, and breeding lines derived from these sources is conferred through the interaction with the same bacterial effector $a v r X v 3$, and the benefit of pyramiding multiple T3 HR-inducing loci would be unclear. However, because H7981 remained virtually disease-free in field experiments when inoculated with race T3 (26) but has been susceptible to other races, it may be desirable to combine $X v 3$ with resistance to other races. Resistance to T1 conferred by $R x-3$ on chromosome 5 is a logical target because the two races continue to appear in surveys of tomato in the Great Lakes region of the United States. Evidence is accumulating for the role of a

TABLE 2. Summary of chromosome 11 marker genotypes for two sources of resistance and susceptible controls

\begin{tabular}{|c|c|c|c|c|c|c|c|}
\hline \multirow[b]{2}{*}{ Marker name } & \multirow[b]{2}{*}{ Type $^{\mathrm{a}}$} & \multirow[b]{2}{*}{ Method $^{b}$} & \multicolumn{3}{|c|}{ Resistant } & \multicolumn{2}{|c|}{ Susceptible } \\
\hline & & & PI $128216^{c}$ & $\mathrm{H} 7981^{\mathrm{d}}$ & IBC $(06.8145)^{\mathrm{e}}$ & OH88119 & OH7870 f \\
\hline SL20244I & Indel & Size PM & 283 & 281 & 283 & 283 & 283 \\
\hline SL10120 & SNP & ASPE & G & $\mathrm{G}$ & A & A & A \\
\hline TOM196 & SSR & Size PM & 207 & 213 & 207 & 210 & 207 \\
\hline TOM144 & SSR & Size PM & 182 & 170 & 182 & 167 & 164 \\
\hline TG400 & SNP & CAPs & $285(\mathrm{G})$ & $320(\mathrm{~A})$ & $285(\mathrm{G})$ & $285(\mathrm{G})$ & $285(\mathrm{G})$ \\
\hline SL20173 & SNP & ASPE & $\mathrm{C}$ & $\mathrm{C}$ & $\mathrm{C}$ & $\mathrm{T}$ & $\mathrm{T}$ \\
\hline SL10615I & Indel & Size PM & 182 & 182 & 182 & 175 & 175 \\
\hline COSOH57 & SNP & CAPs & $145(\mathrm{G})$ & $145(\mathrm{G})$ & $145(\mathrm{G})$ & 216 (A) & $216(\mathrm{~A})$ \\
\hline SL20181 & SNP & ASPE & A & A & A & G & G \\
\hline SL10715 & SNP & ASPE & G & G & G & A & A \\
\hline cLEC-24-C3 & SNP & CAPs & $216(\mathrm{~A})$ & 216 (A) & $216(\mathrm{~A})$ & $196(\mathrm{G})$ & $196(\mathrm{G})$ \\
\hline C2_At1g07960 & SNP & CAPs & $180(\mathrm{C})$ & $200(\mathrm{~T})$ & $180(\mathrm{C})$ & $200(\mathrm{~T})$ & $200(\mathrm{~T})$ \\
\hline SL10027 & SNP & ASPE & A & A & A & $\mathrm{T}$ & $\mathrm{T}$ \\
\hline TG393 & SNP & CAPs & $300(\mathrm{~T})$ & $300(\mathrm{~T})$ & $300(\mathrm{~T})$ & $325(\mathrm{C})$ & $325(\mathrm{C})$ \\
\hline
\end{tabular}

a Indel = insertion/deletion, SNP = single-nucleotide polymorphism, and SSR = simple-sequence repeat.

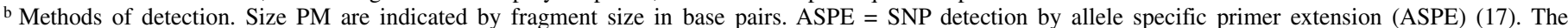
polymorphic base is indicated. CAP $=$ SNP detection by cleaved amplified polymorphism (CAP). The fragment size of the largest polymorphic band is indicated and polymorphic base is indicated in parenthesis.

c PI 128216 is the donor of $R x-4$ from (22)

${ }^{\mathrm{d}} \mathrm{H} 7981$ is the donor of $X v 3$.

e Resistant IBC parent 06.8145 is derived from PI128216 and was used to map $R x-4$.

f $\mathrm{OH} 88119$ and $\mathrm{OH} 7870$ are susceptible parents.

TABLE 3. Allelism tests for hypersensitive reaction (HR) as measured by time to confluent necrosis in tomato plants infiltrated with Xanthomonas perforans race T3

\begin{tabular}{|c|c|c|c|c|c|c|c|}
\hline \multirow[b]{2}{*}{ Controls, crosses ${ }^{a}$} & \multirow[b]{2}{*}{ Pedigree $^{b}$} & \multirow[b]{2}{*}{ Total number of plants } & \multicolumn{2}{|c|}{ Time to confluent necrosis ${ }^{\mathrm{c}}$} & \multirow[b]{2}{*}{ Ratio tested } & \multirow[b]{2}{*}{$\chi^{2}$ test $^{\mathrm{d}}$} & \multirow[b]{2}{*}{$P$ value } \\
\hline & & & $\mathrm{HR}, 24-48 \mathrm{~h}$ & Non-HR 60-72 h & & & \\
\hline H7981 & H7981 & 17 & 17 & 0 & $\ldots$ & $\ldots$ & $\ldots$ \\
\hline 8517 & PI 128216 & 19 & 19 & 0 & $\ldots$ & $\ldots$ & $\ldots$ \\
\hline 8000 & H7981 & 27 & 27 & 0 & $\ldots$ & $\ldots$ & $\ldots$ \\
\hline 8021 & Susceptible (Susc.) & 15 & 0 & 15 & $\ldots$ & $\ldots$ & $\ldots$ \\
\hline$(8000 \times 8111) \mathrm{F}_{1}$ & H7981 × Susc. & 54 & 54 & 0 & $\ldots$ & $\ldots$ & $\ldots$ \\
\hline$(8000 \times 8517) \mathrm{F}_{1}$ & H7981 × PI 128216 & 17 & 17 & 0 & $\ldots$ & $\ldots$ & $\ldots$ \\
\hline$(8517 \times 8021) \mathrm{F}_{1}$ & PI $128216 \times$ Susc. & 17 & 17 & 0 & $\ldots$ & $\ldots$ & $\ldots$ \\
\hline$(8517 \times 8000) \mathrm{F}_{2}$ & PI $128216 \times \mathrm{H} 7981$ & 341 & 341 & 0 & $15: 1$ & 22.38 & $<0.0001$ \\
\hline$(8517 \times 8021) \mathrm{F}_{2}$ & PI $128216 \times$ Susc & 74 & 53 & 21 & $3: 1$ & 0.45 & 0.5 \\
\hline$(8233 \times 8326) \mathrm{F}_{2}$ & PI128216 × PI 126932 & 102 & 102 & 0 & $15: 1$ & 6.8 & $<0.0001$ \\
\hline$(8326 \times 8517) \mathrm{F}_{2}$ & H7981 × PI 128216 & 235 & 235 & 0 & $15: 1$ & 15.67 & $<0.0001$ \\
\hline
\end{tabular}

a Lines 8021 and 8111 were susceptible controls, nonhypersensitive to race T3.

b Sources of resistance.

c Plants were infiltrated with approximately $5 \times 10^{8} \mathrm{CFU} / \mathrm{ml}$.

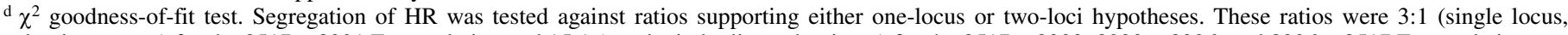
dominant gene) for the $8517 \times 8021 \mathrm{~F}_{2}$ population and $15: 1$ (two loci, duplicate dominant) for the $8517 \times 8000,8233 \times 8326$, and $8326 \times 8517 \mathrm{~F}_{2}$ populations 
QTL conferring multiple race resistance flanked by SSR marker TOM196 (F: CCTCCAAATCCCAAAACTCT, R:TGTTTCATCC ACTATCACGA) and SNP marker COSOH57 (F: TGCCCA AAAGCACAGTACAA, R:CGCCTCCTATCTTCCAAACTT) on chromosome $11(8,45)$. The breeding line Fla. 7600 may provide a good source for combining resistance. It is a large-fruited inbred line with both $R x$-3-mediated $\mathrm{T} 1$ resistance and the chromosome 11 QTL derived from H7998. Thus, crosses to FL7600 could be used for pyramiding HR resistance and selecting for coupling phase recombination to combine T3 HR mediated by $X v 3$ (or $R x$ 4 ) with the quantitative resistance to multiple species of Xanthomonas on chromosome $(8,45)$.

The identification of molecular markers linked to resistance and use of these markers in selection will facilitate pyramiding resistance. The markers identified in this study represent publically available SSR, Indel, and SNP resources that can facilitate breeding goals. Specifically, the SSR markers TOM196 and TOM144 (F: CTGTTTACTTCAAGAAGGCTG, R: ACTTT AACTTTATTATTGCGACG) and the SNP marker COSOH57 would be appropriate to select for the H7998-derived QTL $(8,45)$ while SNP markers cLEC-24-C3 and SL10029 would be appropriate to select for $X v 3$ based on the results of this study. At the same time, the uneven distribution of polymorphisms between the two cultivars and the linkage interval of $20 \mathrm{cM}$ between markers that flank $X v 3$ highlight a need for a concerted effort to develop more molecular markers that are polymorphic among $S$. lycopersicum breeding lines. Multiple resources for marker development are emerging. For example, The International Tomato Genome Sequencing Consortium released a draft of the tomato genome sequence (http://solgenomics.net/). This sequence offers a resource for further marker development as sequence data for other cultivars emerges. With the increased availability of nextgeneration sequencing (21), it is likely that marker development will expand significantly in the near future.

The possibility of allelism, or even identity, of $R x-4$ and $X v 3$ suggests that a revision to the nomenclature of Xanthomonas resistance loci in tomato should be considered. Current notation does not follow a consistent pattern in the literature (Table 1). The locus mapped in this study, $X v 3$, is named in reference to the bacterial effector and the species $X$. vesicatoria. Likewise, HRbased resistance to race T4 identified from LA716 has been named $X v 4$, in reference to a bacterial effector and the bacterial species (2). These designations illustrate the problem with using taxonomic designations in the name because $\mathrm{T} 4$ strains are currently classified as $X$. perforans, not $X$. vesicatoria, under the revised nomenclature (11). Other resistance loci include $R x-1, R x$ 2 , and $R x-3$ that denote loci from $\mathrm{H} 7998$ conferring avrRxvmediated HR resistance to race T1 (47). This designation was maintained in subsequent studies with regards to $R x-3$, which was shown to confer resistance to race $\mathrm{T} 1$ in the field (46). We proposed that the HR-inducing locus identified in PI 128216 be denoted as $R x-4$, which indicates resistance to Xanthomonas locus number 4 (22). Therefore, names currently used in the literature contain a mixture of three systems which reference bacterial effectors, taxonomic species that have been subsequently revised, and sequential naming of loci.

\section{ACKNOWLEDGMENTS}

Funding was provided by United States Department of Agriculture NIFA AFRI grant 2008-55300-04757, Ohio Plant Biotechnology Consortium competitive grant 2007-025, Mid-America Food Processors Association, and the National Natural Science Foundation of China (30972003). H. Wang was supported by the China Scholarship Council State Scholarship Fund 2008635031. We thank T. Aldrich for help with greenhouse and field plantings as well as the Ohio Agricultural Research and Development Center Molecular and Cellular Imaging Center for support of the Luminex genotyping.

\section{LITERATURE CITED}

1. Allard, R. 1956. Formulas and tables to facilitate the calculation of recombination values in heredity. Hilgardia 24:235-278.

2. Astua-Monge, G., Minsavage, G. V., Stall, R. E., Vallejos, C. E., Davis, M. J., and Jones, J. B. 2000. Xv4-avrxv4: A new gene-for-gene interaction identified between Xanthomonas campestris pv. vesicatoria race T3 and the wild tomato relative Lycopersicon pennellii. Mol. Plant-Microbe Interact. 13:1346-1355.

3. Berry, S. Z., Aldrich, T. S., Wiese, K. L., and Bash, W. D. 1995. 'Ohio OX38' hybrid 8 processing tomato. HortScience 30:159.

4. Churchill, G. A., and Doerge, R.W. 1994. Empirical threshold values for quantitative trait mapping. Genetics 138:963-971.

5. Doidge, E. M. 1921. A tomato canker. Ann. Appl. Biol. 7:407-430.

6. Frary, A., Xu, Y., Liu, J., Mitchell, S., Tedeschi, E., and Tanksley, S. D. 2005. Development of a set of PCR-based anchor markers encompassing the tomato genome and evaluation of their usefulness for genetics and breeding experiments. Theor. Appl. Genet. 111:291-312.

7. Hutton, S. F., Scott, J. W., and Jones, J. B. 2010. Inheritance of resistance to bacterial spot race T4 from three tomato breeding lines with differing resistance backgrounds. J. Am. Soc. Hortic. Sci. 135:150-158.

8. Hutton, S. F., Scott, J. W., Yang, W. C., Sim, S. C., Francis, D. M., and Jones, J. B. 2010. Identification of QTL associated with resistance to bacterial spot race T4 in tomato. Theor. Appl. Genet. 121:1275-1287.

9. Jones, J. B., Bouzar, H., Stall, R. E., Almira, E. C., Roberts, P. D., Bowen, B. W., Sudberry, J., Strickler, P. M., and Chun, J. 2000. Systematic analysis of xanthomonads (Xanthomonas spp.) associated with pepper and tomato lesions. Int. J. Syst. Evol. Microbiol. 50:1211-1219.

10. Jones, J. B., Lacy, G. H., Bouzar, H., Minsavage, G. V., Stall, R. E., and Schaad, N. W. 2005. Bacterial spot-world wide distribution, importance and review. Acta Hortic. 695:27-34.

11. Jones, J. B., Lacy, G. H., Bouzar, H., Stall, R. E., and Schaad, N. W. 2004. Reclassification of the xanthomonads associated with bacterial spot disease of tomato and pepper. Syst. Appl. Microbiol. 27:755-762.

12. Jones, J. B., and Scott, J. W. 1986. Hypersensitive response in tomato to Xanthomonas campestris pv. vesicatoria. Plant Dis. 70:337-339.

13. Jones, J. B., Stall, R. E., and Bouzar, H. 1998. Diversity among Xanthomonas pathogens on pepper and tomato. Annu. Rev. Phytopathol. $36: 41-58$.

14. Jones, J. B., Stall, R. E., Scott, J. W., Somodi, G. C., Bouzar, H., and Hodge, N. C. 1995. A third tomato race of Xanthomonas campestris pv. vesicatoria. Plant Dis. 79:395-398.

15. Kabelka, E., Franchino, B., and Francis, D. M. 2002. Two loci from Lycopersicon hirsutum confer resistance to strains of Clavibacter michiganensis subsp. michiganensis. Phytopathology 92:504-510.

16. Labate, J. A., and Baldo, A. M. 2005. Tomato SNP discovery by EST mining and resequencing. Mol. Breed. 16:343-349.

17. Lee, S. H., Walker, D. R., Cregan, P. B., and Boerma, H. R. 2004. Comparison of four flow cytometric SNP detection assays and their use in plant improvement. Theor. Appl. Genet. 110:167-174.

18. Lelliot, R. A., and Stead, D. E. 1987. Methods for the Diagnosis of Bacterial Diseases of Plants. Blackwell Scientific Publication Ltd., Oxford.

19. Minsavage, G. V., Dahlbeck, D., Whalen, M. C., Kearney, B., Bonas, U., Staskawicz, B. J., and Stall, R. E. 1990. Gene-for-gene relationships specifying disease resistance in Xanthomonas campestris pv. vesicatoriapepper interactions. Mol. Plant-Microbe Interact. 3:41-47.

20. Minsavage, G. V., Jones, J. B., and Stall, R. E. 1996. Cloning and sequencing of an avirulence gene ( $a v r X v 3)$ isolated from Xanthomonas campestris pv. vesicatoria tomato race 3. (Abstr.) Phytopathology 86:S15.

21. Nordborg, M., and Weigel, D. 2009. Next-generation genetics in plants. Nature 456:720-723.

22. Robbins, M. D., Darrigues, A., Sim, S. C., Masud, M. A., and Francis, D. M. 2009. Characterization of hypersensitive resistance to bacterial spot race T3 (Xanthomonas perforans) from tomato accession PI 128216. Phytopathology 99:1037-1044.

23. Sahin, F. 1997. Detection, identification and characterization of strains of Xanthomonas campestris pv. vesicatoria by traditional and molecular methods, and resistance in Capsicum species to Xanthomonas campestris pv. vesicatoria pepper race 6. Ph.D. dissertation, The Ohio State University, Wooster.

24. Scott, J. W., Francis, D. M., Miller, S. A., Somodi, G. C., and Jones, J. B. 2003. Tomato bacterial spot resistance derived from PI 114490; inheritance of resistance to race $\mathrm{T} 2$ and relationship across three pathogen races. J. Am. Soc. Hortic. Sci. 128:698-703.

25. Scott, J. W., and Jones, J. B. 1989. Inheritance of resistance to foliar bacterial spot of tomato incited by Xanthomonas campestris pv. vesicatoria. J. Am. Soc. Hortic. Sci. 114:111-114.

26. Scott, J. W., Jones, J. B., and Somodi, G. C. 1995. Screening tomato accessions for resistance to Xanthomonas campestris pv. vesicatoria, race T3. HortScience 30:579-581. 
27. Scott, J. W., Jones, J. B., and Somodi, G. C. 2001. Inheritance of resistance in tomato to race T3 of the bacterial spot pathogen. J. Am. Soc. Hortic. Sci. 126:436-441.

28. Scott, J. W., Miller, S. A., Stall, R. E., Jones, J. B., Somodi, G. C., Barbosa, V., Francis, D. M., and Sahin, F. 1997. Resistance to race T2 of the bacterial spot pathogen in tomato. HortScience 32:724-727.

29. Scott, J. W., Stall, R. E., Jones, J. B., and Somodi, G. C. 1996. A single gene controls the hypersensitive response of $\mathrm{H} 7981$ to race 3 (T3) of the bacterial spot pathogen. Rep. Tomato Genet. Coop. 46:23.

30. Sim, S. C., Robbins, M. D., Chilcott, C., Zhu, T., and Francis, D. M. 2009. Oligonucleotide array discovery of polymorphisms in cultivated tomato (Solanum lycopersicum L.) reveals patterns of SNP variation associated with breeding. BMC Genomics 10:466.

31. Stall, R. E. 1995. Xanthomonas campestris pv. vesicatoria. Pages 167-181 in: Pathogenesis and Host Specificity in Plant Diseases: Histopathological, Biochemical, Genetic and Molecular Bases. U. S. Singh, R. P. Singh, and K. Kphmoto, eds. Elsevier Science, New York.

32. Suliman-Pollatschek, S., Kashkush, K., Shats, H., Hillel, J., and Lavi, U. 2002. Generation and mapping of AFLP, SSRs and SNPs in Lycopersicon esculentum. Cell Mol. Biol. Lett. 7:583-597.

33. Šutic, D. 1957. Bakterioze crvenog patlidzana (tomato bacteriosis). Posebna Izd. Inst. Zasht. Bilja Beograd (Spec. Ed. Inst. Plant Prot. Beograd) 6:1-65. English summary. Rev. Appl. Mycol. 36:734-735.

34. Tanksley, S. D., Ganal, M. W., Prince, J. P., Vicente, D. E., and Bonterbale, M. W. 1992. High density molecular linkage maps of the tomato and potato genomes. Genetics 132:1141-1160.

35. Tudor-Nelson, S. M., Minsavage, G. V., Stall, R. E., and Jones, J. B. 2003. Bacteriocin-like substances from tomato race 3 strains of Xanthomonas campestris pv. vesicatoria. Phytopathology 93:1415-1421.

36. Van Deynze, A., Stoffel, K., Buell, C. R., Kozik, A., Liu, J., van der Knaap, E., and Francis, D. 2007. Diversity in conserved genes in tomato. BMC Genomics 8:465.

37. Van Ooijen, J. W., and Voorrips, R. E. 2001. Joinmap 3: Software for the Calculation of Genetic Linkage Maps. Plant Research International, Wageningen, The Netherlands.
38. Vauterin, L., Hoste, B., Kersters, K., and Swings, J. 1995. Reclassification of Xanthomonas. Int. J. Syst. Bacteriol. 45:472-489.

39. Voorrips, R. E. 2002. MapChart: Software for the graphical presentation of the linkage maps and QTLs. J. Hered. 93:77-78.

40. Wang, J. F., Jones, J. B., Scott, J. W., and Stall, R. E. 1994. Several genes in Lycopersicon esculentum control hypersensitivity to Xanthomonas campestris pv. vesicatoria. Phytopathology 84:702-706.

41. Wang, J. F., Stall, R. E., and Vallejos, C. E. 1994. Genetic analysis of a complex hypersensitive reaction to bacterial spot in tomato. Phytopathology 84:126-132.

42. Wang, Y. Y., Chen, J., Francis, D. M., Shen, H. L., Wu, T. T., and Yang, W. C. 2010. Discovery of intron polymorphisms in cultivated tomato using both tomato and Arabidopsis genomic information. Theor. Appl. Genet. 121:1199-1207.

43. Whalen, M. C., Wang, J. F., Carland, F. M., Heiskell, M. E., Dahlbeck, D., Minsavage, G. V., Jones, J. B., Scott, J. W., Stall, R. E., and Staskawicz, B. J. 1993. Avirulence gene avrRxv from Xanthomonas campestris pv. vesicatoria specifies resistance on tomato line Hawaii 7998. Mol. PlantMicrobe Interact. 6:616-627.

44. Yang, W., Bai X. D., Kabelka, E., Eaton, C., Kamoun, S., van der Knaap, E., and Francis, D. 2004. Discovery of single nucleotide polymorphisms in Lycopersicon esculentum by computer aided analysis of expressed sequence tags. Mol. Breed. 14:21-34.

45. Yang, W., Miller, S. A., Scott, J. W., Jones, J. B., and Francis, D. M. 2005. Mining tomato genome sequence databases for molecular markers: application to bacterial resistance and marker assisted selection. Acta Hortic. 695:241-250.

46. Yang, W., Sacks, E. J., Ivey, M. L., Miller, S. A., and Francis, D. M. 2005. Resistance in Lycopersicon esculentum intraspeciflc crosses to race T1 strains of Xanthomonas campestris pv. vesicatoria causing bacterial spot of tomato. Phytopathology 95:519-527.

47. Yu, Z. H., Wang, J. F., Stall, R. E., and Vallejos, C. E. 1995. Genomic localization of tomato genes that control a hypersensitive reaction to Xanthomonas campestris pv. vesicatoria (Doidge) Dye. Genetics 141:675-682. 